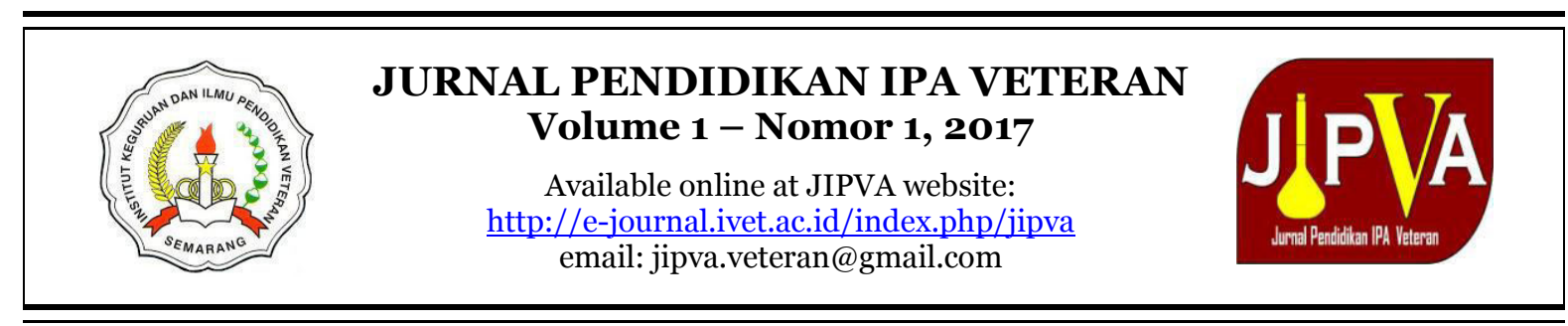

\title{
PENGARUH IMPLEMENTASI MODEL PEMBELAJARAN INKUIRI TERBIMBING KOOPERATIF JIGSAW TERHADAP KETERAMPILAN PROSES SAINS SISWA SMP
}

\author{
Ikhbar Nur Jiwanto*, Sugianto, Khumaedi \\ Program Pascasarjana Universitas Negeri Semarang, Semarang, Indonesia \\ *email: jiwanto_nur@yahoo.com
}

\begin{abstract}
Abstrak
Penelitian ini bertujuan untuk mengetahui pengaruh model pembelajaran inkuiri terbimbing dipadu kooperatif jigsaw dan pengaruh kemampuan akademik awal siswa, serta ada tidaknya hubungan antara model pembelajaran dengan kemampuan akademik awal siswa terhadap keterampilan proses sains siswa SMP. Desain penelitian yang digunakan adalah posttest only control design dengan faktorial $2 \times 3$. Teknik pengumpulan data menggunakan dokumentasi berupa kemampuan akademik awal siswa, lembar observasi dan tes keterampilan proses sains. Hasil penelitian menunjukkan nilai rata-rata skor keterampilan proses sains siswa kelas eksperimen lebih tinggi yaitu 83,70 daripada kelas kontrol yaitu 79.03. Nilai ratarata skor keterampilan proses sains siswa berkemampuan akademik awal tinggi, sedang, dan rendah berturut-turut yaitu 87,00, 81,05, dan 78,38. Dari hasil analisis dapat disimpulkan bahwa model pembelajaran inkuiri terbimbing dipadu kooperatif jigsaw dan kemampuan akademik awal berpengaruh nyata terhadap keterampilan proses sains siswa, serta tidak ada interaksi antara model pembelajaran dengan kemampuan akademik awal siswa terhadap keterampilan proses sains siswa SMP.
\end{abstract}

Kata Kunci : inkuiri terbimbing, kemampuan akademik awal, keterampilan proses sains

\section{THE INFLUENCE OF IMPLEMENTATION OF JIGSAW COOPERATIVE LEARNING INQUIRY MODEL TO SCIENCE PROCESS SKILLS OF JUNIOR HIGH SCHOOL STUDENTS}

\begin{abstract}
This purposes of research are to know the role of guided inquiry learning model with jigsaw cooperative and the role of initial academic ability, and is there any interaction between learning model and initial academic ability to science process skill of Junior High school. This research uses posttest only control design with factorial design $2 \times 3$. Data collections techniques are documentation for initial academic ability, observation sheet and test for science process ability observation. The output of this research shows that the science process skill average score of experiment class is higher that is 83.70 than the control class that is 79.03. Science process skill average score of students with high, moderate, and low initial academic is 87.00, 81.05, and 78.38. Data analysis shows that guided inquiry learning model with jigsaw cooperative and initial academic ability has influence on science process skill of Junior High School students, and there is no interaction between learning model with initial academic ability to science process skill of Junior High School students.
\end{abstract}

Keywords: guided inquiry, initial academic ability, science process skill. 


\section{PENDAHULUAN}

Sains terbentuk dan berkembang melalui suatu proses ilmiah. Pada pembelajaran sains, proses ilmiah tersebut harus dikembangkan terhadap siswa sebagai pengalaman yang bermakna. Sains tidak hanya mengutamakan hasil (produk), tetapi proses juga sangat penting dalam membangun pengetahuan siswa. Jadi, dalam pembelajaran sains, hendaknya siswa dilatih dan dididik agar terampil dalam memperoleh dan mengolah informasi melalui aktivitas berpikir dengan mengikuti prosedur ilmiah, seperti terampil melakukan pengamatan, pengukuran, pengklasifikasian, penarikan kesimpulan, dan pengkomunikasian hasil temuan yang sering disebut keterampilan proses sains. Brickman, et al.(2009) dalam artikelnya menyatakan bahwa keterampilan proses sains dapat berkembang apabila siswa turut berperan aktif dalam kegiatan laboraturium.

Pemilihan model pembelajaran berpengaruh terhadap keberhasilan pembelajaran. Apabila model pembelajaran yang digunakan melibatkan peran aktif siswa dalam proses pembelajaran, maka akan mampu meningkatkan keterampilan proses sains siswa.Berdasarkan studi awal yang dilakukan dengan guru mata pelajaran IPA kelas VIII SMP N 3 Comal, model pembelajaran inkuiri yang menjadikan siswa menjadi lebih aktif dalam proses belajar mengajar jarang dilakukan. Akibatnya, siswa bersifat pasif dalam proses pembelajaran dan keterampilan proses sains siswa tidak berkembang. Salah satu hambatan yang dihadapi dalam proses pembelajaran berbasis inkuiri adalah kurangnya pemahaman guru mengenai model pembelajaran ini sehingga metode pembelajaran ini jarang diterapkan didalam pembelajaran sains (Wenning, 2005).
Permasalahan lain adalah pembelajaran IPA yang dilakukan hanya memberikan kesempatan kepada siswa berkemampuan akademik tinggi memperoleh prestasi yang memuaskan, sedangkan siswa berkemampuan akademik rendah tertinggal prestasinya. Berdasarkan hasil wawancara dengan guru mata pelajaran IPA di SMP N 3 Comal, dampak yang terjadi yaitu jalinan hubungan yang kurang baik antara anak berkemampuan akademik tinggi dengan anak berkemampuan akademik rendah. Pada pembelajaran konvensional, siswa cenderung bersaing untuk mendapatkan peringkat-peringkat yang tinggi dan penghargaan-penghargaan lainnya. Siswa dengan kemampuan akademik rendah tanpa bisa dihindari harus lebih sering berada pada posisi kalah, sehingga perlu upaya untuk meningkatkan keterampilan proses sains siswa berkemampuan akademik rendah. Sebuah solusi yang nyata untuk meningkatkan prestasi anak berkemampuan akademik rendah yaitu dengan pembelajaran kooperatif karena pembelajaran kooperatif menghasilkan hasil belajar yang lebih baik (Ahmad dan Mahmood, 2010).

Berdasarkan permasalahan yang telah diuraikan, maka diharapkan penerapan model pembelajaran inkuiri terbimbing dipadu dengan kooperatif jigsaw yang didalamnya terdapat kelompok belajar akan mendorong siswa saling bertukar pikiran pengetahuan dan konsep belajar. Siswa berkemampuan akademik tinggi yang telah menguasai keterampilan proses sains memberikan tutorial atau bimbingan belajar dalam diskusi kelompok kepada siswa berkemampuan akademik rendah, sehingga melalui proses ini diharapkan dapat memperkecil kesenjangan keterampilan 
Ikhbar Nur Jiwanto, Sugianto, Khumaedi

proses sains antara siswa berkemampuan akademik tinggi dengan siswa berkemampuan akademik rendah.

\section{METODE}

Jenis penelitian ini adalah Quasi exsperimental research dengan desain penelitian Posttest only Control Group Design. Design ini terdapat dua kelompok yang masing-masing dipilih secara random (Sugiyono, 2011). Kelompok yang diberi perlakuan disebut kelompok eksperimen dan kelompok yang tidak diberi perlakuan disebut kelompok kontrol. Penelitian ini menggunakan rancangan faktorial $2 \times 3$ karena dalam penelitian memperhatikan adanya variabel moderator yang mempengaruhi perlakuan (variabel independen) terhadap hasil (variabel dependen). Dalam penelitian ini yang bertindak sebagai variabel moderator adalah kemampuan akademik awal. Kemampuan akademik awal dikategorikan menjadi tiga level yaitu kemampuan akademik tinggi, sedang, dan rendah. Data kemampuan akademik awal diambil dari hasil Ujian Semester I siswa kelas VIII. Skala pengukuran kemampuan akademik siswa dikategorikan berdasarkan mean dan standar deviasi (Sudijono, 2008).

Populasi dalam penelitian ini adalah semua siswa kelas VIII di SMP Negeri 3 Comal tahun pelajaran 2014/2015. Teknik yang digunakan dalam pengambilan sampel adalah teknik simple random sampling yaitu pengambilan anggota sampel dari populasi dilakukan secara acak tanpa memperhatikan strata yang ada dalam populasi itu. Sampel dalam penelitian ini terdiri dari dua kelas, yaitu kelas VIII G sebagai kelas kontrol dan kelas VIII I sebagai kelas eksperimen.
Teknik yang digunakan dalam pengambilan data adalah dokumentasi, tes, dan observasi. Metode dokumentasi digunakan untuk mengetahui kemampuan akademik awal berdasarkan daftar nilai Ujian Semester I kelas VIII. Selain itu juga digunakan untuk melakukan uji kesetimbangan pada dua kelas yang akan dijadikan kelas kontrol dan kelas eksperimen. Teknik pengumpulan data selanjutnya yaitu dengan tes yang digunakan untuk memperoleh data keterampilan proses sains siswa menggunakan tes dalam bentuk pilihan ganda dengan jumlah soal dua puluh. Instrumen tes dalam penelitian ini juga harus diuji cobakan dahulu untuk mengetahui kelayakannya dari segi validitas, reliabilitas, tingkat kesukaran, dan daya beda. Selain tes, pengumpulan data juga dilakukan dengan observasi. Kegiatan observasi dilakukan dalam rangka mengevaluasi peningkatan keterampilan proses sains siswa yang meliputi keterampilan proses dasar dan keterampilan terintegrasi.

Teknik analisa data dibagi menjadi dua yaitu analisis tahap awal dan analisis tahap akhir. Analisis tahap awal (uji prasyarat) dilakukan untuk mengetahui apakah kedua kelas (kelas kontrol dan kelas eksperimen) berangkat dari kondisi awal yang sama (homogen). Data yang digunakan adalah nilai ujian semester sebelumnya mata pelajaran IPA. Analisis data tahap akhir dilakukan setelah kedua sampel diberi perlakuan yang berbeda dan dilakukan tes. Dari tes akhir, akan diperoleh data yang digunakan sebagai dasar dalam menguji hipotesis penelitian. Sebelum dilakukan uji hipotesis dilakukan uji prasyarat atau 
pendahuluan terlebih dahulu yaitu uji normalitas dan homogenitas data akhir (Subana, 2005). Pada pengujian hipotesis, analisis statistik yang digunakan adalah analisis variansi dua jalan (ANAVA dua arah).

Pembelajaran inkuiri terbimbing dipadu kooperatif jigsaw diharapkan dapat dijadikan sebagai salah satu alternatif untuk mewujudkan proses pembelajaran ideal. Maksud pemaduan inkuiri terbimbing dengan jigsaw adalah pemaduan sintaks pembelajaran inkuiri terbimbing dengan tahapan kooperatif jigsaw yang kemudian akan menghasilkan sintaks baru yang akan membimbing siswa melakukan kegiatan ilmiah dalam kelompok.

\section{HASIL DANPEMBAHASAN}

Pengujian hipotesis dilakukan terhadap kelas kontrol dan kelas eksperimen. Data yang diperlukan untuk pengujian ini yaitu data hasil belajar kedua kelompok sampel. Sebelumnya, kelompok kontrol dan kelompok eksperimen dibagi menjadi tiga kelompok berdasarkan kemampuan akademik awal yaitu kemampuan akademik tinggi, kemampuan akademik sedang dan kemampuan akademik rendah. Pada penelitian ini ada tiga hipotesis utama dan untuk menguji ketiga hipotesis tersebut digunakan analisis variansi dua arah (ANAVA dua arah). Hasil perhitungan ANAVA dua arah dapat dilihat pada Tabel 1.

Tabel 1 Ringkasan Perhitungan ANAVA Dua arah

\begin{tabular}{lll}
\hline $\begin{array}{l}\text { Sumber } \\
\text { Varians }\end{array}$ & $\begin{array}{l}\text { Statistik } \\
\text { Uji }\end{array}$ & $\mathbf{F}_{\text {Tabel (0,05) }}$ \\
\hline Baris (A) & $\mathrm{F}_{\mathrm{A}}=11,64$ & $\mathrm{~F}_{\text {Tabel }}=4,02$ \\
Kolom (B) & $\mathrm{F}_{\mathrm{B}}=7,2$ & $\mathrm{~F}_{\text {Tabel }}=3,17$ \\
Interaksi (AB) & $\mathrm{F}_{\mathrm{AB}}=0,14$ & $\mathrm{~F}_{\text {Tabel }}=3,17$ \\
\hline
\end{tabular}

Keterangan :

A : Model pembelajaran

B : Kemampuan akademik awal

AB : Hubungan/interaksi antara model pembelajaran dengan kemampuan akademik awal

Pengaruh Model Pembelajaran Inkuiri Terbimbing Dipadu Kooperatif Jigsaw Terhadap Keterampilan Proses Sains

Berdasarkan hasil perhitungan ANAVA dua arah yang terdapat pada Tabel 1 didapat $\mathrm{F}_{\text {hitung }}=11,64>\mathrm{F}_{\text {tabel }}=4,02$. Ini menunjukkan bahwa keterampilan proses sains siswa antara kelas yang menggunakan model inkuiri terbimbing dipadu jigsaw dan kelas yang menggunakan metode konvensional memiliki perbedaan yang signifikan. Data keterampilan proses sains siswa diperoleh melalui lembar observasi dan nilai posttest. Keterampilan proses sains yang menekankan pada psikomotor menggunakan lembar observasi dan keterampilan proses sains yang menekankan pada kognitif menggunakan tes pilihan ganda. Kedua data tersebut digabung dan dirata-rata sehingga menjadi satu data nilai keterampilan proses sains. Data-data tersebut diambil dari dua kelas, satu kelas kontrol yaitu kelas VIII G menggunakan metode ceramah bervariasi dan satu kelas eksperimen yaitu kelas VIII I menggunakan model pembelajaran inkuiri terbimbing dengan kooperatif jigsaw. Hasil perhitungan distribusi keterampilan proses sains siswa dapat dilihat secara ringkas pada Tabel 2. 
Ikhbar Nur Jiwanto, Sugianto, Khumaedi

Tabel 2. Data Akhir Hasil

KeterampilanProses Sains Siswa

BerdasarkanModel Pembelajaran

\begin{tabular}{lll}
\hline Interval & $\begin{array}{l}\text { Frekuensi Kelas } \\
\text { Kontrol }\end{array}$ & $\begin{array}{l}\text { Frekuensi Kelas } \\
\text { Eksperimen }\end{array}$ \\
\hline $66-69$ & 2 & 1 \\
$70-73$ & 4 & 0 \\
$74-77$ & 6 & 2 \\
$78-81$ & 8 & 4 \\
$82-85$ & 5 & 9 \\
$86-89$ & 5 & 9 \\
$90-93$ & 0 & 3 \\
Mean & 79,03 & 83,7 \\
Standart & 5,99703 & 5,471872 \\
Deviasi & & \\
Varience & 35,96437 & 29,94138 \\
Minimum & 66 & 68 \\
Maximum & 89 & 92 \\
$\mathrm{~N}$ & 30 & 30 \\
\hline
\end{tabular}

Dari Tabel 2 menunjukkan bahwa nilai rata-rata keterampilan proses sains di kelas eksperimen yang menggunakan inkuiri terbimbing lebih tinggi dibandingkan dengan kelas kontrol yang menggunakan metode ceramah bervariasi. Hal ini didukung oleh Brickman, et al. (2009) dalam jurnalnya bahwa keterampilan proses sains dapat berkembang apabila siswa ikut berperan aktif dalam kegiatan laboratorium dengan pembelajaran inkuiri. Keterampilan proses sains yang diukur dalam penelitian ini meliputi keterampilan proses dasar dan keterampilan proses terintegrasi. Keterampilan proses dasar terdiri atas mengamati, mengkomunikasikan, dan menyimpulkan. Dari hasil penilaian siswa melalui lembar observasi terhadap pelaksanaan dari tiap-tiap aspek keterampilan proses sains, diperoleh hasil seperti ditunjukkan pada Gambar 1.

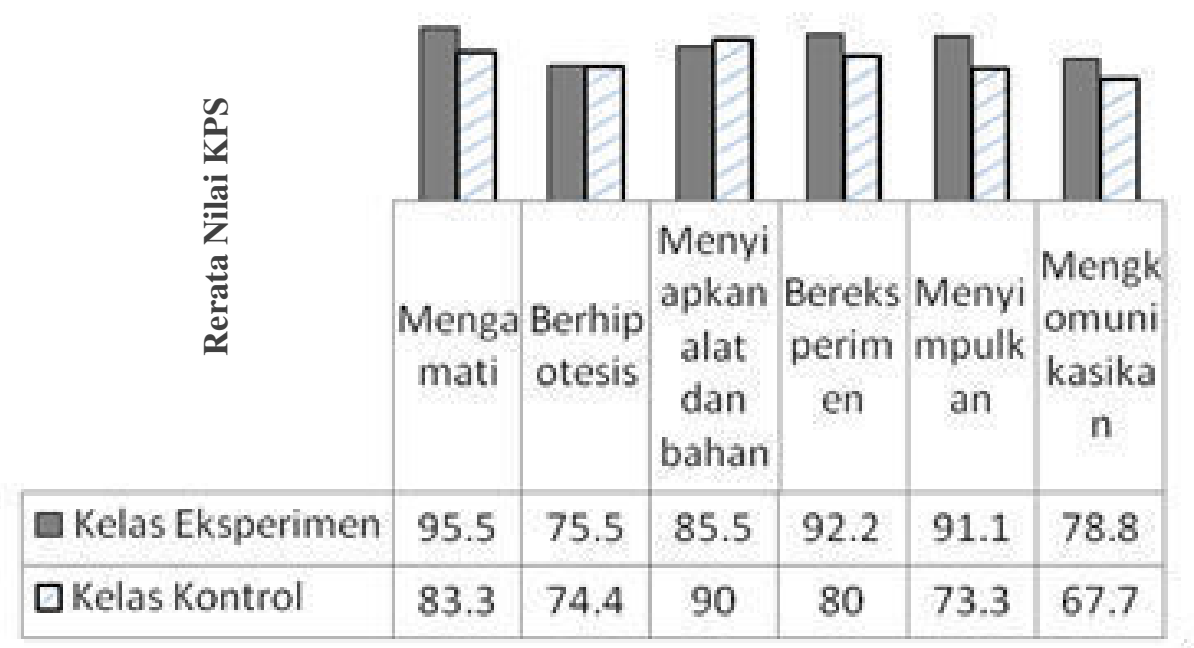

Gambar 1 Perbandingan Skor Tiap Aspek Keterampilan Proses Sains 
Hasil pengamatan dalam pembelajaran inkuiri terbimbing, siswa memiliki kesempatan yang luas untuk menumbuhkan dan meningkatkan keterampilan proses sains melalui kegiatan penyelidikan seperti yang dilakukan oleh seorang ilmuan yaitu melakukan pengamatan, merumuskan permasalahan, melakukan hipotesis, merancang penelitian untuk menguji hipotesis, mengumpulkan data dan menganalisis untuk membuat kesimpulan. Masing-masing tahapan inkuiri terbimbing membelajarkan siswa akan keterampilan proses sains. Hal ini didukung oleh Ozdilek \& Bulunuz (2009) yang menyatakan bahwa model inkuiri terbimbing mampu meningkatkan keterampilan proses siswa.

Pada pembelajaran kooperatif jigsaw guru mendesain siswa untuk belajar dalam kelompok-kelompok kecil. Pembelajaran yang didesain guru melalui kelompokkelompok kecil akan lebih efektif dan memudahkan siswa dalam memahami materi pelajaran. Koopeatif jigsaw memfasilitasi terjadinya komunikasi sosial antar siswa yang dengan kemampuan akademik berbeda melalui tutorial teman sebaya. Siswa akan lebih memahami suatu konsep materi ketika berada di lingkungan teman sebanya yang lebih pintar (Kilic, 2008). Siswa lebih memahami materi pelajaran karena bahasa komunikasi yang digunakan siswa dalam menyampaikan materi pelajaran. Interaksi sosial dengan teman lain melalui kerja kelompok juga memacu terbentuknya ide dan memperkaya perkembangan mental anak.

Perpaduan sintaks pembelajaran inkuiri terbimbing dipadu kooperatif jigsaw mampu meningkatkan keterampilan proses sains karena dalam pembelajaran ini siswa dikondisikan untuk melakukan kegiatan ilmiah mulai dari merencanakan percobaan sampai dengan melaksanakan percobaan melalui bimbingan guru. Proses-proses ilmiah inilah yang akan menumbuhkan sikap ilmiah siswa. Kooperatif jigsaw menempatkan siswa pada kelompok kecil yang berbeda kemampuan akademik, mengakomodasi siswa untuk saling berinteraksi sosial dengan teman sebanya sehingga terjadi proses tutorial teman sebaya dimana proses ini akan membantu siswa yang berkemampuan akademik rendah dan sedang, kemampuan proses sainsnya mendekati keterampilan proses sains siswa yang mempunyai kemampuan akademik tinggi.

\section{Pengaruh Kemampuan Akademik Awal Terhadap Keterampilan Proses Sains}

Berdasarkan hasil perhitungan ANAVA dua arah yang terdapat pada tabel 1 pada bagian efek kemampuan akademik awal siswa terhadap keterampilan proses sains didapat $F_{\text {hitung }}=7,2>F_{\text {tabel }}=3,17$. Hal ini menunjukkan ada perbedaan yang signifikan antara siswa yang memiliki kemampuan akademik tinggi, sedang, dan siswa yang memiliki kemampuan akademik rendah terhadap keterampilan proses sains. Perbandingan keterampilan proses sains ditinjau dari kemampuan akademik awal tinggi, sedang dan rendah pada kelas kontrol dan eksperimen dapat dilihat pada tabel 3.

Tabel 3. Data Rerata KPS Berdasarkan Kemampuan Akademik Awal

\begin{tabular}{cc}
\hline $\begin{array}{c}\text { Kemampuan Akademik } \\
\text { Awal }\end{array}$ & $\begin{array}{c}\text { Rata-rata } \\
\text { KPS }\end{array}$ \\
\hline Tinggi & 87,00 \\
Sedang & 81,05 \\
Rendah & 78,38 \\
\hline
\end{tabular}

Berdasarkan Tabel 3 menunjukkan bahwa rata-rata keterampilan proses sains siswa yang berkemampuan akademik awal tinggi pada kelas eksperimen lebih tinggi daripada rata-rata siswa berkemampuan akademik awal tinggi pada kelas kontrol. 
Ikhbar Nur Jiwanto, Sugianto, Khumaedi

Siswa dengan kemampuan akademik awal sedang pada kelas eksperimen juga menunjukkan rata-rata yang lebih tinggi dibandingkan dengan kelas kontrol. Keterampilan proses sains pada siswa dengan kemampuan akademik rendah pada kelas eksperimen juga menunjukkan ratarata yang lebih tinggi daripada rata-rata keterampilan proses sains siswa yang berkemampuan akademik awal rendah pada kelas kontrol. Perbandingan rerata hasil keterampilan proses sains berdasarkan kemampuan akademik awal pada kelas kontrol dan eksperimen dapat dilihat pada Gambar 2.

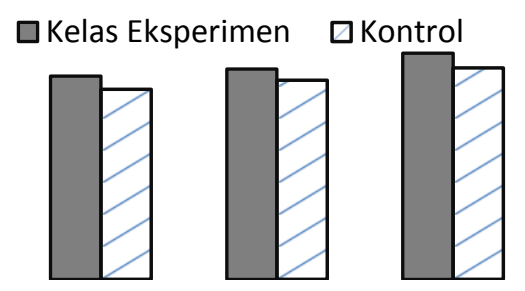

Gambar 2. Perbandingan Nilai Rata-Rata KPS Ditinjau dari KemampuanAkademik awal.

Kemampuan akademik siswa menurut Nasution (2000) diklasifikasikan menjadi tiga yaitu kemampuan akademik atas, sedang, dan bawah. Siswa akademik atas cenderung mempunyai prestasi belajar lebih tinggi dibandingkan dengan siswa akademik bawah.Winarni (2006) menyatakan bahwa siswa berkemampuan tinggi adalah sejumlah siswa yang memiliki keadaan awal lebih tinggi dari rata-rata kelas, sedangkan siswa yang berkemampuan rendah adalah sejumlah siswa yang memiliki keadaan awal lebih rendah atau sama dengan rata-rata kelas. Siswa berkemampuan tinggi memiliki keadaan awal lebih baik daripada siswa berkemampuan awal rendah. Hal ini menyebabkan siswa berkemampuan tinggi memiliki rasa percaya diri yang lebih dibandingkan dengan siswa yang berkemampuan rendah. Model pembelajaran merupakan salah satu perlakuan berupa faktor eksternal yang dapat mempengaruhi keterampilan proses sains siswa dan kemampuan akademik merupakan salah satu faktor internal yang dapat mempengaruhi keterampilan proses sains siswa.

\section{Hubungan Antara Model Pembelajaran dan Kemampuan Akademik Awal Terhadap Keterampilan Proses Sains}

Pada hasil perhitungan ANAVA dua arah yang terdapat pada tabel 1 untuk mengetahui hubungan antara model pembelajaran dengan kemampuan akademik awal terhadap keterampilan proses sains siswa didapat $\mathrm{F}_{\text {hitung }}=0,14<\mathrm{F}_{\text {tabel }}=3,17$. Hasil ujianava menunjukkan tidak adanya interaksi antara penerapan model pembelajaran dengan kemampuan akademik awal terhadap keterampilan proses sains siswa. Hasil ini memberikan makna bahwa tidak ada perbedaan yang signifikan pada setiap interaksi penerapan model pembelajaran dengan kemampuan akademik awal siswa. Jadi tidak ada perbedaan antara penerapan model inkuiri terbimbing dipadu kooperatif jigsaw yang diterapkan pada siswa berkemampuan akademik rendah, sedang, maupun tinggi dengan model konvensional yang diterapkan pada siswa berkemampuan akademik rendah, sedang, maupun tinggi. Siswa yang memiliki kemampuan akademik rendah, sedang, maupun tinggi dapat mengikuti pembelajaran dengan model inkuiri 


\section{8 | JIPVA Veteran, Volume 1-Nomor 1, 2017}

terbimbing dipadu kooperatif jigsaw maupun model konvensional serta mampu meningkatkan keterampilan proses sainsnya. Model pembelajaran merupakan salah satu perlakuan berupa faktor eksternal yang dapat mempengaruhi keterampilan proses sains siswa. Sedangkan kemampuan akademik merupakan salah satu faktor internal yang dapat mempengaruhi keterampilan proses sains siswa. Keterampilan proses sains siswa pada kelompok eksperimen dengan penerapan model inkuiri terbimbing dipadu kooperatif jigsaw selalu lebih tinggi dibanding keterampilan proses sains kelompok kontrol dengan penerapan model pembelajaran konvensional baik dilihat dari kemampuan akademik tinggi, sedang dan rendah.

\section{SIMPULAN DAN SARAN}

Berdasarkan hasil penelitian dapat disimpulkan bahwa model pembelajaran inkuiri terbimbing dipadu kooperatif jigsaw dan kemampuan akademik awal berpengaruh terhadap keterampilan proses sains siswa SMP kelas VIII, serta tidak ada interaksi atau hubungan antara model pembelajaran dengan kemampuan akademik awal siswa terhadap keterampilan proses sains siswa SMP kelas VIII. Untuk penelitian lebih lanjut, diharapkan mencoba memadukan model inkuiri terbimbing dengan pembelajaran kooperatif yang lain, sehingga memungkinkan mendapatkan hasil yang lebih baik.

\section{DAFTAR PUSTAKA}

Ahmad, Z. \& Mahmood, N. 2010. Effects of Cooperative Learning vs. Traditional Instruction on Prospective Teachers' Learning Experience and Achievement. Journal of Faculty of Educational Sciences. $\quad 43 \quad$ (1):154-164. http://www.ankara.edu.tr
Brickman, P., Gormally, C., Armstrong, N., \& Hallar, B. 2009. Effects of Inquiry-based Learning on Students' Science Literacy Skills and Confidence. International Journal for the Scholarship of Teaching and Learning, 3 (2) : 116.http://www.georgiasouthem.edu /ijsotl

Kilic, D. 2008. The Effect of The Jigsaw Technique on Learning The Concepts of The Principles and Methods of Teaching. World Applied Sciences Journal. 4 (3) : 109-114 .http://idosi.org/wasj/wasj4\%28s 1 $\% 29 / 18 . p d f$

Nasution. 2000. Berbagai Pendekatan dalam Proses Belajar Mengajar. Jakarta: Bumi Aksara.

Ozdilek, Z. \& Bulunuz, N. 2009. The Effect of a Guided Inquiry Method on Pre Service Teachers Science Teaching Self Efficacy Beliefs. Journal of Turkish science education. 6 (2) : 24-39. http://www.ankara.edu.tr

Subana. 2005. Statistik Pendidikan. Bandung: Pustaka Ceria.

Sudijono, A. 2008. Pengantar Evaluasi Pendidikan. Jakarta: Raja Grafindo.

Sugiyono. 2011. Metode Penelitian Pendidikan Pendekatan Kuantitatif, Kualitatif, dan $R$ \& D. Bandung: Alfabeta.

Wenning. C. J. 2005. Implementing Inquiry Based Instruction in The Science Classroom : A New Model for Solving The Improvement of Practice Problem. Journal Physich Teacher Education Online. 2 (4) : 9-15.

http://www.phy.ilstu.edu/jpteo

Winarni. 2006. Pengaruh Strategi Pembelajaran terhadap Pemahaman Konsep IPA-Biologi, Kemampuan Berpikir Kritis, dan Sikap Ilmiah Siswa Kelas V SD dengan Tingkat Kemampuan Akademik Berbeda di Kota Bengkulu. Disertasi.Malang: Program Pascasarjana UM. 